\title{
Rasio Bekatul Padi dengan Pelarut pada Ekstraksi Minyak Bekatul Padi
}

\author{
Fajriyati Mas'ud $^{1, a}$ dan Pabbenteng ${ }^{1, b}$ \\ ${ }^{1}$ Jurusan Teknik Kimia, Politeknik Negeri Ujung Pandang \\ J1. Perintis Kemerdekaan KM.10 Makassar-90245 \\ afajri28672@gmail.com \\ bbento_fathir@ymail.com
}

\begin{abstract}
Rice bran oil is the oil extracted from rice bran. This is edible oil that is very good for health so that potential as a functional food, and can be develop the agroindustry. Solvent extraction process is done using $n$-heksane and ethanol. The purpose of this study was to determine the best ratio of rice bran with n-heksane and ethanol to obtain the highest percentage of the oil. The main ingredient of this study is rice bran, $n$-heksane and ethanol. The extraction process is done at a temperature of $55^{\circ} \mathrm{C}, 200 \mathrm{rpm}$ for 5 hours. The results showed that the best ratio of bran and n-heksan to produce the ultimate percentage of oil is $1: 7$ that is equal to $7,53 \%$, as well as the best ratio of bran and ethanol to produce the ultimate percentage of oil is $1: 6$ that is equal to $8,49 \%$.
\end{abstract}

Keywords- Rice bran oil, solvent extraction, n-hexane, and ethanol

\begin{abstract}
Abstrak - Minyak bekatul padi adalah minyak yang diekstraksi dari bekatul padi, merupakan minyak nabati yang sangat baik untuk kesehatan sehingga potensial sebagai pangan fungsional, dan dapat dikembangkan pada bidang agroindustri. Proses ekstraksi pelarut dilakukan dengan menggunakan n-heksana dan etanol. Tujuan dari penelitian ini adalah untuk menentukan rasio terbaik bekatul padi dengan n-heksana dan etanol untuk memperoleh persentase minyak tertinggi. Bahan utama dari penelitian ini adalah bekatul padi, n-heksana dan etanol. Proses ekstraksi dilakukan pada suhu $55^{\circ} \mathrm{C}, 200 \mathrm{rpm}$ selama 5 jam. Hasil penelitian menunjukkan bahwa rasio terbaik bekatul dengan n-heksan untuk menghasilkan persentase minyak yang tertinggi adalah 1: 7 yaitu sebesar 7,53\%, sedangkan rasio terbaik bekatul dengan etanol untuk menghasilkan persentase minyak tertinggi adalah 1: 6 yaitu sebesar $8,49 \%$.
\end{abstract}

Kata kunci: minyak bekatul padi, ekstraksi pelarut, n-heksana, etanol

\section{Pendahuluan}

Bekatul marupakan lapisan luar biji-bijian sereal, terdiri atas kulit ari (aleuron) dan pericarp. Bekatul bersama dengan lembaga dipisahkan selama penggilingan dan penyosohan sereal untuk tujuan estetika, sifat organoleptik dan daya tahan sereal [1]. Bekatul padi berasal dari lapisan dalam kulit padi (bran) yang terpisah dari beras saat penyosohan selama penggilingan, memiliki warna kuning kecoklatan dengan aroma sama seperti aroma berasnya. Bekatul segar hanya memiliki umur simpan 24 jam, setelah itu bekatul harus diawetkan untuk diolah menjadi bebagai produk [2]. Bekatul padi mengandung minyak, protein, karbohidrat, dan serat pangan, juga kaya dengan berbagai jenis senyawa fenolik [3], juga mengandung sejumlah senyawa fitokimia seperti senyawa fenolik, vitamin, minyak, derivatif steroid, polisakarida dan protein [4].

Minyak bekatul padi mengandung beberapa jenis lemak yaitu 47\% lemak mono unsaturated, 33\% polyunsaturated dan $20 \%$ saturated serta asam lemak yaitu asam oleat $38,4 \%$, linoleat $34,4 \%$ linolenat $2,2 \%$, palmitat $21,5 \%$ dan stearat 2,9\%. Minyak bekatul memiliki aroma dan tampilan yang baik serta nilai titik asap yang cukup tinggi $\left(254^{\circ} \mathrm{C}\right)$. Dengan titik asap yang paling tinggi dibandingkan minyak nabati lainnya maka minyak bekatul merupakan minyak terbaik dibanding minyak kelapa, minyak sawit maupun minyak jagung [5].

Minyak bekatul padi mengandung rasio saturated acid: monounsaturated acid: polyunsaturated acid sekitar 1:2.2:1.5 yang merupakan rasio yang optimal bagi kesehatan manusia menurut rekomendasi WHO, terutama mengandung asam oleat $36-38 \%$, linoleat $35-38 \%$ dan $\alpha-$ linolenat $1.8-2.4 \%$ yang merupakan asam lemak tak jenuh, serta asam palmitat $21-25 \%$ dan stearat $2.7-3.0 \%$ yang merupakan asam lemak jenuh [6,7]. Komponen utamanya adalah triasilgliserol berjumlah sekitar $80 \%$ dari minyak bekatul padi kasar. Tiga asam lemak utama terdiri dari palmitat, oleat dan linoleat dengan kisaran kandungan asam lemak berturut-turut adalah $12-18 \%$, 40-50\%, dan 20-42\%. Komponen lainnya adalah digliserida 2-3\%, monogliserida 5-6\%, asam lemak bebas 2-3\%, wax 0,3\%, glikolipid 0,8\%, pospolipid $1,6 \%$, dan senyawa tak tersabunkan $4 \%[8]$.

Minyak bekatul padi mengandung senyawa fitokimia dalam jumlah yang tinggi. Senyawa ini mempunyi aktivitas sebagai antioksidan alami, terutama $\alpha, \beta, \gamma, \delta$ tokoferol dan tokotrienol, serta fraksi oryzanol [9]. Tokoferol, $\gamma$-oryzanol dan ß-karoten merupakan golongan antioksidan non polar yang berfungsi menghambat proses peroksidasi lemak dan mencegah stres oksidatif.

Melihat potensi minyak bekatul padi yang sangat baik sebagai pangan fungsional, maka penelitian diarahkan untuk mengkaji proses ekstraksinya yang dapat menghasilkan rendemen yang tinggi dengan biaya yang 
murah. Tujuan penelitian ini adalah untuk mengetahui rasio bekatul dengan pelarut terbaik pada ekstraksi minyak bekatul padi. Metode ekstraksi dilakukan secara bertingkat, pelarut yang digunakan adalah n-heksan dan etanol. Dengan metode ekstraksi bertingkat menggunakan pelarut non polar dilanjutkan dengan pelarut polar maka diharapkan semua komponen minyak dapat terekstraksi dengan maksimal.

Metode ekstraksi yang dilakukan merupakan proses ekstraksi padat-cair atau leaching. Leaching adalah proses pemisahan suatu zat terlarut yang terdapat dalam suatu padatan dengan mengontakkan padatan tersebut dengan pelarut (solvent) sehingga padatan dan pelarut bercampur dan kemudian zat terlarut terpisah dari padatan karena larut dalam pelarut. Pada ekstraksi padat cair terdapat dua fase yaitu fase overflow (ekstrak) dan fase underflow (rafinat/ampas) [10].

Mekanisme yang terjadi selama ekstraksi adalah pembilasan senyawa-senyawa dalam sel tanaman ke luar dari sel tanaman, dan melarutnya kandungan senyawa kimia oleh pelarut keluar dari sel tanaman melalui proses difusi dengan 3 tahapan, yaitu: 1) penentrasi pelarut ke dalam sel tanaman sehingga terjadi pengembangan (swelling) sel tanaman, 2) proses disolusi yaitu melarutnya kandungan senyawa di dalam pelarut, 3) difusi dari senyawa tanaman, keluar dari sel tanaman.

Interaksi diantara komponen terlarut dari padatan sangat berpengaruh pada proses ekstraksi. Pada proses ekstraksi ini, komponen terlarut yang terperangkap di dalam padatan, bergerak melalui pori-pori padatan. Zat terlarut berdifusi keluar permukaan partikel padatan dan bergerak ke lapisan film sekitar padatan, selanjutnya ke larutan.

Beberapa faktor yang mempengaruhi kesetimbangan konsentrasi dalam ekstraksi yaitu perbandingan jumlah sel tanaman dan pelarut, proses difusi sel yang utuh, lama perendaman dan pengembangan sel tanaman, kecepatan proses disolusi sel tanaman yang terintegrasi, kecepatan terjadinya kesetimbangan, suhu dan $\mathrm{pH}$ interaksi senyawa terlarut dan tidak larut, dan tingkat kepolaran pelarut [11].

Beberapa faktor dapat mempengaruhi proses ekstraks, antara lain adalah jenis dan jumlah pelarut. Semakin banyak jumlah pelarut semakin banyak pula jumlah produk yang akan diperoleh, hal ini dikarenakan distribusi partikel dalam pelarut semakin menyebar, sehingga memperluas permukaan kontak, dan perbedaan konsentrasi solut dalam pelarut dan padatan semakin besar [12].

\section{Metode Penelitian}

\section{A. Lokasi dan Waktu Penelitian}

Penelitian dilaksanakan di Laboratorium Kimia Dasar dan Kimia Analisis, Jurusan Teknik Kimia, Politeknik Negeri Ujung Pandang pada bulan Mei hingga Agustus 2016.

\section{B. Alat dan Bahan}

Peralatan yang digunakan dalam penelitian ini yaitu autoclave Hiclave HV-85 merk HIRAYAMA, oven pengering Ecocell, sieving, talang, wadah plastik, timbangan analitik, hot plate, reactor labu gelas leher empat, oil bath, motor pengaduk IKA-WERK RW 20, thermometer, refrigerated centrifuge $\mathrm{AX}-521$, rotavapor Buchi R-215 yang dilengkapi vacuum pomp V-700, botol sampel, dan alat-alat gelas.

Bahan-bahan yang digunakan adalah bekatul padi dari varietas IR-64 yang diperleh dari penggilingan padi rakyat di Makassar, pelarut n-heksan teknis dan ethanol 96\% yang diperoleh dari toko bahan kimia di Makassar.

\section{Prosedur Penelitian}

Penelitian dilakukan melalui 2 tahap utama, yaitu proses stabilisasi bekatul padi dan proses ekstraksi minyak bekatul padi.

Proses stabilisasi bekatul padi

Bekatul padi yang baru terpisah dengan beras segera distabilisasi menggunakan autoklaf $110^{\circ} \mathrm{C}$ dengan perlakuan $3,6,9,12$, dan 15 menit untuk menonaktifkan lipase penyebab ketengikan dan untuk melunakkan jaringan bekatul guna memudahkan proses ekstraksi minyak. Selanjutnya dikeringkan pada oven $40^{\circ} \mathrm{C}$ selama 5 jam. Bekatul kering diayak 60 mesh dan dikemas dalam wadah plastik bertutup menunggu proses ekstraksi.

Proses ekstraksi minyak bekatul padi

Bekatul padi ditimbang $100 \mathrm{~g}$ dan dimasukkan dalam reaktor labu gelas leher empat, ditambahkan pelarut nheksan disetiap perlakuan sebanyak 300, 400, 500, 600, 700, dan $800 \mathrm{~mL}$, labu dihubungkan dengan kondensor, dan motor pengaduk serta dimasukkan dalam oil bath. Ekstraksi berlangsung pada $200 \mathrm{rpm}$ dengan perlakuan suhu $55^{\circ} \mathrm{C}$ selama 5 jam. Selanjutnya bagian padatan dan cairan dipisahkan dengan sentrifugasi pada $3500 \mathrm{rpm}$ selama 15 menit, minyak dengan n-heksan dipisahkan pada rotavapor yang bekerja pada kondisi kecepatan putaran 60 
rpm, suhu pemanasan $35^{\circ} \mathrm{C}$, dan suhu penguapan $21^{\circ} \mathrm{C}$, sehingga persentase perolehan minyak $(\mathrm{b} / \mathrm{b})$ dapat diketahui menggunakan rumus:

$$
\%=\frac{\text { berat minyak }(\mathrm{gr})}{\text { berat gamrel }(\mathrm{gr})} \times 100 \%
$$

Ampas bekatul selanjutnya diekstraksi lebih lanjut dengan etanol mengikuti prosedur yang sama dengan ekstraksi n-heksan.

\section{III.Hasil dan Pembahasan}

Ekstraksi minyak bekatul padi dapat menggunakan pelarut n-heksan dan etanol, karena pelarut ini aman dan umum digunakan dalam proses ekstraksi bahan makanan. Etanol disebut juga etil alkohol yang di pasaran lebih dikenal sebagai alkohol yang merupakan senyawa organik dengan rumus kimia $\mathrm{C}_{2} \mathrm{H}_{5} \mathrm{OH}$. Pada suhu ruang etanol berwujud cairan yang mudah menguap, mudah terbakar, tak berwarna dengan titik didih $78,32^{\circ} \mathrm{C}$. Heksan adalah senyawa hidrokarbon alkane dengan rumus kimi $\mathrm{C}_{6} \mathrm{H}_{14}$, dalam keadaan standar senyawa ini merupakan cairan tak berwarna yang tidak larut dalam air, dengan titik didih $69^{\circ} \mathrm{C}$ [13]. Pada proses ekstraksi dapat dipilih pelarut yang mudah dipisahkan dari zat terlarut untuk dapat digunakan kembali. Oleh karena itu, pelarut biasanya dipilih bertitik didih rendah [14].

Pada butir gabah terdapat lipase, enzim ini tidak aktif tetapi segera menjadi aktif saat kulit gabah (sekam) dihancurkan dalam proses penggilingan padi. Aktivitas lipase ini akan terus berlangsung selama penyimpanan, dan dengan demikian kadar asam lemak bebas dalam bekatul makin meningkat. Untuk mengatasi hal ini biasanya bekatul untuk bahan baku minyak makan, lipase diinaktivasi terlebih dahulu sebelum penyimpanan. Waktu stabilisasi bekatul padi menggunakan panas bertekanan pada suhu $110^{\circ} \mathrm{C}$ cukup sampai 12-15 menit (Gambar 1), sebab persentase perolehan minyak akan menurun bila proses dilanjutkan. Menonaktifkan lipase pada bekatul padi dibutuhkan suhu $100-120^{\circ} \mathrm{C}$, apabila pemanasan lebih lama maka akan membuat komponen yang terkandung menjadi rusak dan berpengaruh terhadap rendemen minyak. Bekatul yang distabilisasi dengan pemanasan kering dapat bertahan hingga 30 hari tanpa perubahan kandungan asam lemak bebas [15].

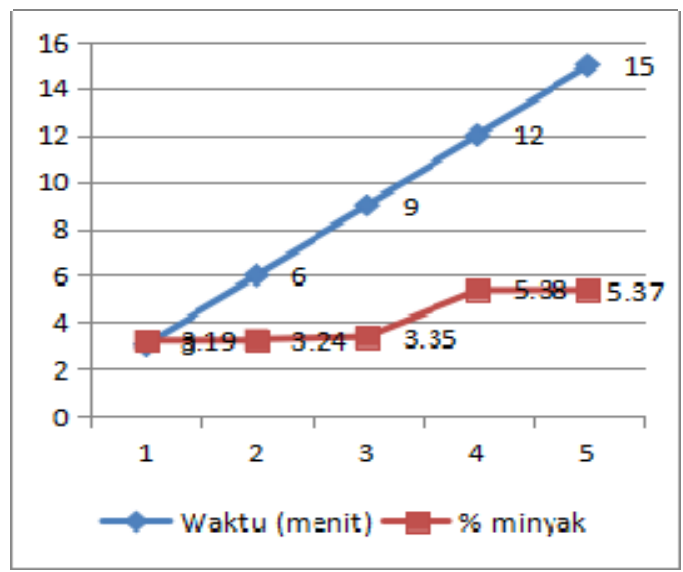

Gambar 1. Efek waktu stabilisasi bekatul padi terhadap rendemen minyak

Gambar 2 memperlihatkan hasil ekstraksi minyak bekatul padi dengan n-heksan dan etanol yang dilakukan secara bertingkat. Secara umum dapat dijelaskan bahwa pada minyak bekatul padi terdapat komponen polar yang lebih banyak dibanding komponen non-polar, hal tersebut dapat dibuktikan dari hasil yang diperoleh dimana persentase perolehan minyak hasil ekstraksi etanol lebih tinggi dibanding hasil ekstraksi dengan n-heksana.

Rasio bekatul padi dengan n-heksan mencapai hasil maksimum pada rasio 1:7, sedangkan rasio bekatul padi dengan etanol mencapai hasil maksimum pada rasio 1:6, jika jumlah pelarut ditambah maka persentase perolehan minyak sudah menurun, hal tersebut terkait dengan jumlah pelarut sudah mencapai titik maksimum untuk mengekestraksi minyak pada bekatul. Secara umum persentase perolehan minyak mengalami peningkatan seiring bertambahnya jumlah pelarut yang digunakan. Semakin banyak jumlah pelarut yang digunakan maka semakin besar pula kemampuan pelarut untuk mengambil minyak yang terkandung pada bekatul padi. Semakin banyak jumlah pelarut mengakibatkan semakin lama waktu kontak yang terjadi antara bahan dengan pelarut. 


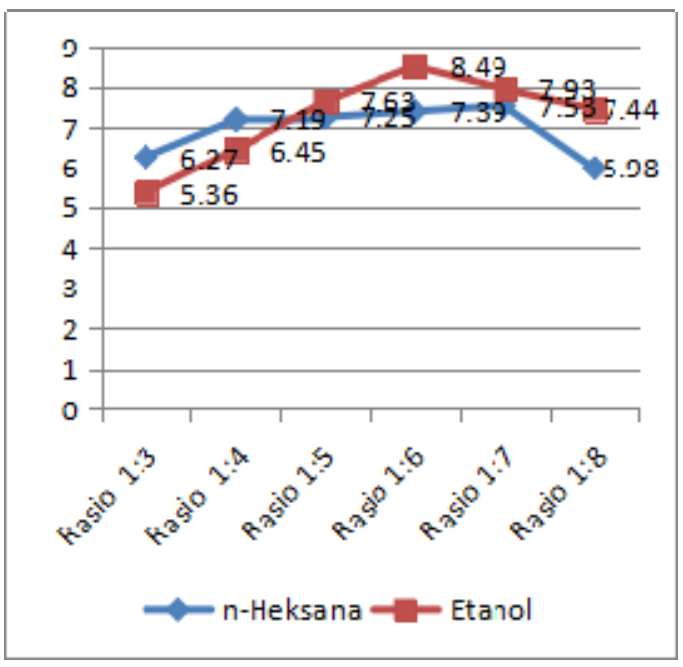

Gambar 2. Efek rasio bekatul padi dengan pelarut n-heksana dan etanol pada ekstraksi bertingkat minyak bekatul padi

Pada proses ekstraksi minyak dengan pelarut, perpindahan massa minyak dari dalam padatan ke pelarut dapat diduga melalui tahapan difusi dari dalam padatan ke permukaan padatan, dan perpindahan massa minyak dari permukaan padatan ke pelarut. Operasi ekstraksi padat cair dapat dilakukan dengan cara mengontakkan padatan dan pelarut sehingga diperoleh larutan yang diinginkan yang kemudian dipisahkan dari padatan sisanya. Pada saat pengontakkan terjadi, mekanisme yang berlangsung adalah peristiwa pelarutan dan difusi. Pelarutan merupakan peristiwa penguraian suatu molekul zat menjadi komponennya, baik berupa molekul-molekul, atom-atom maupun ion-ion, karena pengaruh pelarut cair yang melingkupinya. Partikel-partikel yang terlarutkan ini berkumpul dipermukaan antara padatan (interface) dan terlarut. Bila peristiwa pelarutan masih terus berlangsung, maka terjadi difusi partikel-partikel zat terlarut dari lapisan antara fase menembus lapisan permukaan pelarut dan masuk ke dalam badan pelarut dimana zat terdistribusikan merata. Jadi difusi terjadi dari fase padat diikuti difusi ke fase cair. Peristiwa ini terus berlangsung sehingga keadaan setimbang tercapai.

Distribusi pelarut ke padatan akan sangat berpengaruh pada perolehan minyak, perbandingan antara padatan dengan pelarut akan mempengaruhi rendemen yang dihasilkan. Banyaknya pelarut mempengaruhi luas kontak padatan dengan pelarut, semakin banyak pelarut maka luas kontak akan semakin besar, sehingga distribusi pelarut ke padatan akan semakin besar. Meratanya distribusi pelarut ke padatan akan memperbesar rendemen yang dihasilkan, banyaknya pelarut akan mengurangi tingkat kejenuhan pelarut, sehingga komponen yang diinginkan akan terekstrak dengan sempurna [16].

\section{Kesimpulan}

Pada proses ekstraksi minyak bekatul padi menggunakan pelarut $n$-heksan dan etanol yang dilakukan secara bertingkat, diketahui bahwa rasio bekatul dengan nheksan terbaik untuk mengekstraksi minyak bekatul padi adalah 1:7 dengan persentase perolehan minyak sebanyak $7,53 \%$, dan selanjutnya rasio bekatul dengan etanol terbaik untuk mengekstraksi minyak bekatul padi adalah 1:6 dengan persentase perolehan minyak sebanyak $8,49 \%$.

\section{Daftar Pustaka}

[1] Van der Kamp, J. W. , Poutanen, K., Seal, C. J., and Richardson, D. P. 2014. The HEALTHGRAIN definition of "whole grain. Food \& Nutrition Research, 58.

[2] Rizqie Aulina, 2011. Manfaat bekatul dan kandungan gizinya. Makalah. Disampaikan pada Pertemuan Paguyuban Ibu-ibu Perumahan Puri Domas Sempu Wedomartani Ngemplak Sleman, Yogyakarta.

[3] Omid Pouralia, Feridoun Salak Asgharib, Hiroyuki Yoshidaa, 2010. Production of phenolic compounds from rice bran biomass under subcritical water conditions. ScienceDirect. Chemical Engineering Journal 160: 259-266.

[4] Seema Patel. 2015. Cereal bran fortified-functional foods for obesity and diabetes management: Triumphs, hurdles and possibilities. ELSEVIER, ScienceDirect, Journal of functional foods 14: 255269.

[5] Hadipernata M., 2007. Mengolah dedak menjadi minyak (rice bran oil). Warta Penelitian dan Pengembangan Pertanian. Bogor: Balai Besar Penelitian dan Pengembangan Pascapanen Pertanian; 29(4):810 .

[6] Gopala Krishna AG, Hemakumar KH, Khatoon S., 2006. Study on the composition of rice bran oil and its higher free fatty acids value. J Amer Oil Chem Soc; 83:117-20.

[7] Dilini Bopitiya and Terrence Madhujith, 2014. Antioxidant Potential of Rice Bran Oil. Prepared from Red and White Rice. Tropical Agricultural Research Vol. 26 (1): 1-11.

[8] Luh, B.S., 2005. Rice: Production and Utilization, AVI Publishing Company, Inc., USA, 1980.

[9] $\mathrm{Xu} \mathrm{Z,} \mathrm{Hua} \mathrm{N,} \mathrm{Godber} \mathrm{JS.,} \mathrm{2001.} \mathrm{Antioxidant} \mathrm{activity} \mathrm{of}$ tocopherols, tocotrienols and $\quad \gamma$-oryzanol components from rice bran against cholesterol oxidation accelerated by 2,2'-azobis(2-methylpropionamidine) dihydrocholoride. J. Agric. Food Chem.; 49: 2077-81.

[10] McCabe, Warren.L.,1993. Operasi Teknik Kimia jilid 2. Erlangga: Jakarta.

[11] Gamse, T., 2002. Liquid-Liquid Extraction and Solid-Liquid Extraction\|, Institute of Thermal Process and Environmental Engineering, Graz University of Technology: 2-24.

[12] Munawaroh, Safaatul dan Handayani Prima Astuti, 2010. Ekstraksi minyak daun jeruk purut (Citrus hystrix D.C.) dengan Pelarut etanol dan N-Heksana. Jurnal Kompetensi Teknik, 2 (1): 73-78.

[13] Bustan, MD., Ria Febriyani dan Halomoan Pakpahan, 2008. Pengaruh waktu ekstraksi dan ukuran partikel terhadap oleoresin jahe yang diperoleh dalam berbagai jumlah pelarut organik. Jurnal Teknik Kimia, No. 4, Vol. 15. 
[14] Subriyer Nasir, Fitriyanti, dan Hilma Kamila, 2009. Ekstraksi dedak padi menjadi minyak mentah dedak padi (crude rice bran oil) dengan pelarut $n$-hexane dan ethanol. Jurnal Teknik Kimia, No. 2, Vol. 16.

[15] Kim, J.S., Godber, J.S., 2001. Oxidativ estability and vitamin E levels increased in restructured beef roast with added rice bran oil. Journal of Food Quality 24, 17-26.

[16] Jayanudin, Ayu Zakiyah Lestari, dan Feni Nurbayanti, 2014. Pengaruh suhu dan rasio pelarut ekstraksi terhadap rendemen dan viskositas natrium alginate dari rumput laut coklat (Sargassum $s p$ ) . Jurnal Integrasi Proses Vol. 5, No. 1: 51 - 55 . 